\title{
Perspective
}

Expert insights on a timely policy issue

\section{Israel's Iran Policies After the Nuclear Deal}

\author{
Dalia Dassa Kaye
}

L or more than a decade, Israel has been at the forefront of efforts to expose and prevent an Iranian nuclear weapon capability. Through threats of military force, support for increased international sanctions, and alleged sabotage and assassinations of Iranian nuclear scientists, Israel has made its position clear that it will not accept a nuclear-armed Iran. Prime Minister Benjamin Netanyahu has clearly stated that he views Iran as an existential threat to Israel. While not all Israeli decisionmakers view Iran as an existential threat, most view a nuclear weaponcapable Iran as an unacceptable challenge to Israel and regional stability. At times, Israeli security leaders and analysts have differed in their approaches to confronting Iran, particularly over Netanyahu's handling of the U.S. relationship, as well as the advisability of a military option. Despite such differences, Israel's political and security establishments are largely unified in their opposition to Iranian nuclear ambitions and share similar assessments about what they perceive as malign Iranian intentions toward the Jewish state and its destabilizing regional activities.
It is thus not surprising that Israel was one of the most vocal opponents of the nuclear negotiations with Iran that initially led to an interim nuclear agreement in November 2013 between Iran and the so-called P5+1 (Germany and the five members of the United Nations Security Council: the United States, Russia, China, France, and the United Kingdom). ${ }^{1}$ Israeli officials remained wary of the nuclear negotiations in the months following the interim agreement, particularly since these officials were not a party to the negotiations and had limited influence over the process. ${ }^{2}$ Israeli leaders suggested stringent conditions for a final agreement that many Western analysts deemed to be unfeasible, such as a nearly complete dismantlement of Iran's civilian nuclear infrastructure. Some Israeli analysts questioned Israel's ability to influence the negotiations without taking more-flexible positions. ${ }^{3}$ Other Israeli leaders were critical not just of the terms being negotiated but of the fact that the Western powers were willing to negotiate with Iran at all, arguing that Iran could not be trusted to honor any agreement. Israeli leaders made no secret of their unease with normalizing Iran's relationship with 
the international community through a nuclear agreement, raising questions about whether Israeli leaders were taking tough positions to facilitate a "better agreement" or to prevent negotiators from reaching any agreement at all. ${ }^{4}$

Such questions became moot once the world powers and Iran reached a final agreement, the Joint Comprehensive Plan of Action (JCPOA), on July 14, 2015.5 Israeli leaders quickly condemned the agreement. Netanyahu famously called it a "historic mistake."6 Despite some positive assessments in Israel's security community about the value of rolling back the Iranian nuclear program for a number of years, the overwhelming majority of political and security leaders in Israel remained highly skeptical of the JCPOA and Iran's broader regional intentions.

Yet, remarkably, after years of Israel making the Iran nuclear file its top national security priority and months of contentious debate that severely tested the U.S.-Israeli relationship, once the agreement became a reality by September 2015, the nuclear issue quickly moved off the radar in Israel's political and public discourse. In the months following the agreement, debates over Israel's policies toward the Palestinians and particularly Syria eclipsed the Iran nuclear issue. The continuing spillover from the Syrian civil war and the "knife intifada" reminded Israelis of more-proximate security threats. To be sure, concerns about Iran did not vanish; they just evolved from a focus on the nuclear issue to Iran's ability to threaten Israel in nonnuclear spheres, particularly through its support for Hizballah and its growing presence in Syria, on Israel's northern border.

Israel's views of Iran will no doubt continue to evolve as the Iran nuclear agreement is fully implemented, flounders, or ultimately unravels. But Israel's response following the agreement and preparations for the future already signal likely Israeli postures in the years to come, as well as potential flash points that could threaten regional stability and U.S. national security interests. This report will thus examine not only Israel's immediate responses to the final agreement but also how Israeli postures and policy options vis-à-vis Iran are developing in the post-deal environment.

\section{Israeli Positions on the Joint Comprehensive Plan of Action}

As expected, the official Israeli response to the final nuclear agreement was hostile. Yet many Israeli leaders and analysts criticized the prime minister's handling of the negotiations and particularly the friction his stance created with the Barack Obama administration. Prominent voices in Israel's security community expressed less alarmist views, although the overwhelming consensus was one of continued mistrust and concern about Iran's broader nonnuclear postures toward Israel. Most Israeli leaders and analysts expect Iran to comply with the agreement at least in the early years, because they believe that the agreement works in Iran's favor. What concerns them is what Iran will do in the nonnuclear areas as the agreement moves forward, particularly if the agreement emboldens Iran to become more aggressive in Syria, Lebanon, and the broader region. Israelis are also concerned about maintaining international attention on the agreement after five years or so and the capabilities Iran might acquire after key elements of the agreement terminate in ten to fifteen years, even if Iran remains a party to the Nuclear Nonproliferation Treaty (NPT). ${ }^{?}$

\section{The Official Reaction: A "Historic Mistake"}

Responding to the announcement of the JCPOA on July 14, 2015, Netanyahu called it a "stunning historic mistake" and noted that 
Israel was not bound by the agreement, "because Iran continues to seek [Israel's] destruction." 8 The foreign minister at the time, the Yisrael Beytenu party chair Avigdor Lieberman, compared the deal with the Munich Agreement with Nazi Germany. ${ }^{9}$ Moshe Yaalon, then Israeli defense minister, said that the agreement was built on "lies and deceit" and that it is a "tragedy for all who aspire to regional stability and fear a nuclear Iran. . . . Instead of fighting terror with all its might, the free world has granted legitimacy to Iran's hateful, murderous ways." 10

Opposition to the deal focused not only on what Israelis saw as shortcomings in the agreement itself but also on concerns that the agreement would embolden Iran in other nonnuclear areas. ${ }^{11}$ Israeli officials and analysts argued that the deal legitimized Iran as a nuclear threshold state and would leave nuclear capabilities and nuclear research and development in place that would allow Iran to remain dangerously close to weaponizing its program once the agreement expired (or even during the duration of the agreement if Iranian cheating were not detected). Israeli leaders also expressed skepticism over the verification measures in the agreement given Iran's past violations and the predominant Israeli view that Iran is determined to become a nuclear-armed regional power. Israeli officials also worried that Iran will "play in gray areas" and that the international community would not confront Iran over small violations because the United States and its allies had invested so much political capital in the agreement. ${ }^{12}$

Another central Israeli concern was the sanctions relief that Iran would receive as part of the agreement. The Israeli critique was that Iran would use the economic windfall from sanctions relief to increase funding for subversive regional activities, particularly support for terrorist groups, military adventurism in Syria, and more-advanced missile development. ${ }^{13}$ Some Israeli officials argued that Iran's extensive terrorist network and ballistic missile advances suggested not only regional but also global ambitions. ${ }^{14}$ Amos Gilad, a senior Israeli defense official, asserted that Iran's missile development constituted an unprecedented threat, with more than 100,000 Iranian rockets aimed at Israel..$^{15}$

In the months following the July 2015 agreement, the Israeli government's approach was to support efforts in the U.S. Congress to derail the deal. Even before the final agreement was signed in Vienna, Israeli officials indicated that the Israeli government "won't be shy about making its views on the Iran deal heard on Capitol Hill." ${ }^{16}$ Foreign Ministry Director General Dore Gold argued, "To the extent that Israeli officials are asked about their views, they should inform members of Congress what Israel thinks." ${ }^{17}$ Indeed, Netanyahu's controversial address to Congress in March 2015, despite objections from the White House and leading congressional Democrats, was widely viewed as an attempt to persuade Congress to challenge the agreement. Because House Speaker John Boehner invited Netanyahu to address Congress without the knowledge and support of the White House, the speech was viewed as highly partisan, further straining relations between the prime minister and Obama.

\section{In the months following the July 2015 agreement, the Israeli government's approach was to support efforts in the U.S. Congress to derail the deal.}


Once the agreement was finalized, in July, Israeli leaders again pinned their hopes on Congress overturning the agreement during a sixty-day review period. ${ }^{18}$ The pro-Israel lobby, the American Israel Public Affairs Committee (AIPAC), launched a major and ultimately unsuccessful campaign to persuade members of Congress to oppose the agreement, an effort some claim was made more difficult by the perceived direct and partisan Israeli intervention into U.S. politics. ${ }^{19}$ In the end, Congress did not take action to overturn the agreement, which the administration presented as a successful diplomatic achievement that prevented a nuclear-armed Iran without having to go to war and was supported by all world powers. The JCPOA proceeded to "adoption day" on October 18, 2015. ${ }^{20}$ After the International Atomic Energy Agency (IAEA) certified that Iran had met its obligations under the agreement to restrict key elements of its nuclear program, the JCPOA began its implementation phase on January 16, 2016, triggering the lifting of nuclear-related sanctions. ${ }^{21}$

\section{Differences with the Prime Minister Emerged over His Handling of the Negotiations and the U.S. Relationship, but Not His Fundamental Views of Iran}

Domestic Israeli critique of Netanyahu's opposition to the agreement focused largely on how he handled his relationship with the United States during the nuclear negotiations and his public attempts to appeal to Congress to derail the agreement. Analysts viewed Netanyahu's speech to Congress in March 2015 as particularly damaging to Israel's relationship with the United States, jeopardizing bipartisan support for Israel with his "crude interference in American politics." ${ }^{22}$ Netanyahu's speech to Congress also occurred during the height of an election within Israel, leading to accusations that he was pursuing such a confrontational approach to appear strong on the international stage for a domestic Israeli audience, despite the risk of harming relations with the United States. But, as one analyst noted, Netanyahu's approach to challenging the deal in the U.S. Congress was viewed by some as a needlessly futile effort that would only result in "more unnecessary bad blood between the Netanyahu government and the Obama administration" and undermine Israel's negotiating position with the United States on post-deal security assurances. ${ }^{23}$

Even Israeli leaders who were highly critical of the nuclear deal, such as Lieberman, criticized the prime minister's approach, particularly his public opposition to the U.S. position that led Americans and others to "simply laugh at [Israelis] when [they] start to talk about Iran." ${ }^{24}$ Giora Eiland, a former national security adviser, also viewed the JCPOA as a "bad agreement" but argued that a confrontational approach should be abandoned in favor of a dialogue with the United States, where "Israel can request returns in the defense world." 25

Political-opposition figures were particularly critical of the way in which Netanyahu handled the nuclear file, perhaps more so because the confrontation with the United States came during an election in Israel. The critique of Netanyahu's approach to the negotiations and his rift with the U.S. government became a regular talking point for such opposition leaders as Isaac Herzog and Amos Yadlin. Haim Ramon, a former member of the Knesset and a former minister for the Labor and Kadima parties, called Netanyahu's nuclear stance a "march of folly" that "led to a strategic, military, economic, diplomatic and social disaster." ${ }^{26}$ Tzipi Livni, a member of Knesset, criticized the prime minister for failing to stop the agreement and damaging Israel's strategic relationship 
with the United States: "Iran grows stronger despite the objections of Israel, the strategic alliance with the United States becomes a contentious issue, American Jewry has been severely harmed, and the security compensation that will be given to Israel now will be worse than what we could have received." ${ }^{27}$ Israeli analysts and Iran experts also voiced concern about Israeli tactics in opposing the agreement that led Israel to become "irrelevant" in the final stages of the negotiations. ${ }^{28}$

Yet despite this critique of Netanyahu's approach, most opposition leaders shared Netanyahu's fundamental assessment of the Iranian leadership and its ambitions. ${ }^{29}$ Herzog, a leader of the Labor Party, even joined Netanyahu in condemning the JCPOA, arguing that the deal "will unleash a lion from the cage, it will have a direct influence over the balance of power in [Israel's] region," as well as that the deal is "going to affect [Israel's] borders" because Iran is an "empire of evil and hate that spreads terror across the region." ${ }^{30}$ And former Labor ministers, such as Ephraim Sneh, who had expressed concern about Iran's nuclear program since the early 1990s, called the lifting of sanctions in January 2016 a "black day" for Israel. ${ }^{31}$ For Sneh, the agreement gave in to most of Iran's demands while legitimizing Iran in the international community and reinforcing its hegemonic ambitions. Israeli leaders often express a concern that the international community will start viewing Iran as a constructive player in confronting such groups as ISIS rather than as part of the problem, ${ }^{32}$ and that the international community will make concessions to Iran that undermine Israel's security in exchange for Iranian actions that benefit the West.

Netanyahu and other political leaders proclaim to see little difference between Iran and the Islamic State and other extrem-
Once the agreement was completed and the fight in Congress ended, there was little else Israel could do on the matter, and the Iran nuclear challenge no longer remained a major issue in the Israeli domestic arena.

ist Islamic movements. As Sneh put it, the deal enables Iran "to become a dominant factor in strategic affairs. . . . [T] he Iranians were invited as equal partners to the talks on Syria. They are also deviously playing the Islamic State card, saying, 'We'll help you [fight] against them.' It's convenient to believe the Iranians, but what exactly is the big difference between the two? It's just a different version of the same barbaric Muslim fascism." ${ }^{33}$ Sneh's assessment of Iran and its intention to destroy Israel largely aligns with Netanyahu's analysis and rhetoric. Nonetheless, Sneh is critical of the rift the prime minister caused with the Obama administration, undermining Israel's ability to prevent the deal or at least modify it, because Sneh claims that "Netanyahu chose to follow the interests of the Republican Party rather than Israel's own security interests." 34

The near universal critiques of Netanyahu's diplomatic strategy for preventing the nuclear agreement are overshadowed by an equally overwhelming political consensus that views the agreement as enhancing Iran's regional power in ways that endanger Israeli security. It is thus not surprising that for all the controversy over Netanyahu's congressional speech and friction with the United States, the prime minister did not face political repercussions within Israel following the deal. ${ }^{35}$ Once the agreement was com- 
pleted and the fight in Congress ended, there was little else Israel could do on the matter, and the Iran nuclear challenge no longer remained a major issue in the Israeli domestic arena.

\section{The Israeli Security Establishment Is Less Hostile to the JCPOA Than Members of the Political Elite Are, but lts Broader}

\section{Assessment of Iran Is Similar}

Mirroring the sentiments of the political leadership, the current Mossad head, Yossi Cohen, has argued that Iran is an even more formidable threat following the nuclear agreement because it "continues to call for Israel's destruction, it upgrades [Iran's] military capabilities and deepens its grip in [Israel's] area . . . via its tentacles of terror." ${ }^{36}$ But others in Israel's security establishment have expressed less alarmist views about the agreement and even see some value in it. In a speech to the Washington Institute for Near East Policy in September 2015, following the failure to thwart the deal in the U.S. Congress, the former chief of the general staff of the Israel Defense Forces (IDF), Lieutenant General Benjamin Gantz, shared a more mixed assessment of the agreement. Gantz argued, "[While] a better deal could have been reached[,] . . . I also see the half-full part of the glass here. ... And I see the achievement of keeping away the Iranians for ten, fifteen years into the future-and postponing their capabilities of having a nuclear capability — and with the right price." ${ }^{37}$ Gantz goes on to argue that this is a "done deal" that in his assessment does not threaten Israel's security situation: "We are the strongest country in the [Middle East]; we know how to take care of ourselves. . . . So I refuse to get hysterical on this." ${ }^{38}$ A former Israeli defense official similarly noted that the Iran issue has decreased in importance for the IDF general staff, where some leaders believed that too much attention and resources had been invested on Iran. ${ }^{39}$
In a speech to the Institute for National Security Studies in Tel Aviv, in January 2015, the chief of staff of the IDF, Lieutenant General Gadi Eizenkot, referred to the nuclear agreement as a "strategic turning point" that brought risks but also opportunities for Israel. ${ }^{40}$ Eizenkot was less focused on the threat stemming from Iran's nuclear program following the agreement than on Iran's support for regional actors hostile to Israel—particularly Hizballahwhich Eizenkot saw as the IDF's foremost military rival. ${ }^{41}$

A number of Israeli military and security analysts similarly see the JCPOA as having succeeded in at least postponing the Iranian program and believe that it is a better outcome than the alternatives. ${ }^{42}$ Despite calling the nuclear agreement "highly problematic," in part because it "legitimizes Iran's status as a nuclear threshold state," the former military intelligence head Amos Yadlin still viewed some positive nuclear gains at least in the short term. Yadlin argued that the agreement extends Iran's breakout time to a year and establishes a verification regime "that is much more invasive than the current system. . . . For at least the next ten years, the threat of nuclear armament in Iran has been reduced. ${ }^{43}$ The former Mossad head Efraim Halevy also argued that the agreement blocks the "road to Iranian nuclear military capabilities for at least a decade." ${ }^{44}$ Other Israeli security analysts have similarly praised the deal for delaying the Iranian nuclear weapons threat for ten to fifteen years, which they view as a better outcome for Israel's security than the possibility that Iran could develop a weapon in a matter of months in the absence of the JCPOA. ${ }^{45} \mathrm{~A}$ former Israeli security official sees an improvement for Israel with the Iranian nuclear program rolled back for up to fifteen years, even if all of the Israeli government's "bad dreams are becoming a reality" with respect to Iran's nonnuclear activity-terrorist links, 


\section{Israeli security analysts have ... praised the deal for delaying the Iranian nuclear weapons threat for ten to fifteen years, which they view as a better outcome for Israel's security than the possibility that Iran could develop a weapon in a matter of months in the absence of the JCPOA.}

missile tests, human rights abuses. ${ }^{46}$ Even the key Israeli panel that advises the Israeli government on nuclear issues, Israel's Atomic Energy Commission, reportedly endorsed the JCPOA, finding the agreement's inspection measures and constraints on Iranian plutonium and uranium enrichment sufficient to prevent Iran's ability to produce a nuclear bomb. ${ }^{47}$

That said, some Israeli analysts believe the reported fissures between the security and political establishment over the nuclear deal are overblown. As one former Israeli security official put it, "out of 600 ex-generals and officials, 500 were with Bibi [Netanyahu] on Iran, even if those same 500 would be against Bibi on Israeli-Palestinian issues." ${ }^{8} 8$ In this analyst's view, while the "deal isn't a disaster," in the longer term, Iran will be just "weeks away from a bomb" and meanwhile will use sanction relief "to develop dangerous weapon systems. ${ }^{349}$ Others in the Israeli security community largely share this assessment of the agreement's negative impact on broader regional security, even if they see some shortterm benefits on the nuclear front. One analysis summarizes the common Israeli perception that the deal provides a strategic boost for Iran despite the immediate nuclear rollbacks: "The JCPOA effectively recognizes Iran's status as a nuclear threshold state. . . . The combination of its nuclear program, unfreezing of funds, and international legitimacy is liable to further empower Iran, bolster its self-confidence and freedom of action, increase its gravitational pull as a regional power, and detract from the Western powers' ability to oppose Iran on various issues." ${ }^{\text {0 }}$

Such concerns over Iran's longer-term intentions are common among Israeli security elites, suggesting that overall assessments of Iran are not fundamentally different from the prevailing political consensus, even among those who were highly critical of the way the prime minister handled the nuclear file. Like the political elite, most Israeli security analysts do not believe that Iranian behavior will moderate during the duration of the JCPOA, an argument often heard in Western debates over the nuclear agreement. The primary difference within the Israeli establishment is that security elites are more inclined than political leaders to see at least shortterm benefits of the JCPOA in diplomatically setting back Iran's nuclear program while avoiding unnecessary friction with the United States. Continued concern about broader Iranian activity in the region is prevalent among both security and political elites.

It is also important to note that Israeli analysts who favored the nuclear agreement and those who opposed it largely assess the prospects for Iranian compliance with the JCPOA to be high. Security analysts and former defense officials who see at least short-term benefits from the agreement believe that it will be difficult for Iran to cheat given the verification measures in place to enforce the agreement; their primary concern is what happens when key elements of the deal expire in ten to fifteen years. ${ }^{51}$ Those 
more skeptical of the JCPOA still believe that Iran is unlikely to violate the agreement because they assess that it ultimately works in Iran's favor, allowing it to reap economic benefits while bolstering conventional military capabilities and preparing for a nuclear option down the road. ${ }^{52}$ Others opposed to the agreement — such as Netanyahu's former national security adviser, Yaacov Amidrorenvision scenarios where Iran might cheat even before the full expiration of the agreement but in either case argue that Iran is likely to pursue nuclear weapons once the agreement ends in ten to fifteen years. ${ }^{53}$

Some Israeli arms control experts maintain a highly critical view of the JCPOA even in the short term. Emily Landau of the Institute for National Security Studies has written a number of critiques of the agreement, expressing concern not only about its time frame but also its failure to restrict continued Iranian nuclear research and development and a "totally ambiguous" verification mechanism. ${ }^{54}$ In Landau's view, because Iran has lied about its nuclear program in the past, the terms of the agreement should have been more stringent. ${ }^{55}$ A former Israeli arms control official similarly expressed concerns about the enforcement of the agreement, particularly on such issues as the potential military dimensions of Iran's program, procurement channels, and inspections that could set dangerous precedents that will "haunt the United States for the next decade." ${ }^{\prime 6}$ In this former official's view, it is not clear whether the deal will even last a decade before Iran cheats.

Despite such concerns among some Israeli arms control experts, the consensus view emerging in Israel's broader security community is that the agreement puts the nuclear challenge on the backburner for up to ten years and that Iran is likely to abide by it. ${ }^{57}$ The focus has largely shifted to Iran's nonnuclear threats to
Israel, particularly Iran's continued missile development; continued political and military support to anti-Israel militant groups such as Hizballah; and a newly aggressive stance in southern Syria, in the Golan, which puts Islamic Revolutionary Guard Corps (IRGC) Qods forces on Israel's border.

\section{Israeli Policies and Options After the JCPOA}

Despite their strident opposition to the JCPOA, Israeli leaders largely adapted to the reality of the agreement as they shifted focus to nonnuclear areas of concern and began preparations for the future. In October 2015, then-Defense Minister Moshe Yaalon, who had forcefully argued against the agreement, acknowledged the new strategic context in a joint press conference with U.S. Defense Secretary Ashton Carter: "The Iran deal is a given. Our disputes are over. And now we have to look to the future."58

\section{A Shift in Focus Away from the Nuclear File to Iran's Nonnuclear Activities, Particularly Iran's Role in Syria}

Given the intensity of the debate over the nuclear agreement during the spring and summer of 2015, it is remarkable how quickly the nuclear file moved off the Israeli political agenda once the deal survived congressional efforts to overturn it. One major factor that might explain this rapid shift in focus is the surge of violent attacks by Palestinians beginning in October 2015, following attempts by Jewish nationalists to pray on the Temple Mount. In the following months Israelis faced a series of so-called lone-wolf stabbings and car attacks from young Palestinians, leading to the deaths of dozens of Israeli and hundreds of Palestinians killed by the IDF in response. The string of attacks led to an unprecedented rift between Israel's security and political establishments 


\section{But while Palestinian violence might have contributed to the downgrading of the Iran nuclear issue in Israeli domestic debates, the conflict in Syria quickly became the predominant concern among Israel's security establishment.}

over the appropriate role of the IDF in responding to Palestinian violence and the role of the IDF in Israeli society. ${ }^{59}$ While Iran is associated with Palestinian attacks through its support for Hamas, particularly during the 2014 Gaza conflict, Israelis viewed the renewed Palestinian violence that occurred on the heels of the Iran deal as more homegrown. And such violence is what preoccupied Israelis in the year following the nuclear agreement, helping to explain the sudden and "radical shift" of focus away from the nuclear issue following the agreement. ${ }^{60}$

But while Palestinian violence might have contributed to the downgrading of the Iran nuclear issue in Israeli domestic debates, the conflict in Syria quickly became the predominant concern among Israel's security establishment. ${ }^{61}$ Of course, Israeli concerns about Syria directly relate to Iranian influence and regional power projection, just not to Iran's nuclear program. Indeed, a wide array of Israeli analysts and military officials view Iran's regional position and confidence as having strengthened following the nuclear agreement. As one former official and analyst explained, in the Israeli view, the agreement led the international community to view Iran as a legitimate player in the region, increasing Iran's leverage in Syria. ${ }^{62}$

The most immediate challenge is Iran's close relationship with Hizballah and Iran's supply of advanced weaponry to the group. While some Israeli officials and analysts assess that much of Iran's economic windfall from the nuclear deal will be invested domestically, they are nonetheless concerned about increased funding for the IRGC Qods force and Hizballah. One official explained, “Another \$500 million from Iran to Hizballah isn't a lot for Iran but would be a huge difference for Hizballah." 63

Israelis are especially concerned about the growing presence of Iranian forces on Israel's border in the Syrian Golan region. ${ }^{64} \mathrm{~A}$ high-ranking IRGC general was reportedly killed in an Israeli airstrike in January 2015, although it is not known whether Israel was aware that the general was in the Golan at the time or intended to kill him. ${ }^{65}$ Still, the growing Iranian presence in the Syrian Golan increases the potential for escalation, even if unintended. As a former Israeli security official explained, Bashar al-Assad opened up Syria to Iran and Hizballah, allowing Iranian cells to emerge that are likely to be part of any postconflict settlement. ${ }^{66}$ Israeli officials see such a permanent Iranian or Hizballah presence on the Golan border as unacceptable, essentially creating a new redline vis-à-vis Iran that has little to do with its nuclear program. ${ }^{67}$

Although Israeli officials have not publicly acknowledged it, it is widely believed that Israel has launched multiple airstrikes within Syria to target weapon shipments to Hizballah, including strikes that led to the killing of the Iranian general. The potential transfer of advanced weapons to Hizballah in Syria is viewed as a redline 


\section{The growing Iranian presence in the Syrian Golan increases the potential for escalation, even if unintended.}

for Israel that it has acted on in the past. ${ }^{68}$ Some Israeli analysts believe that Netanyahu made an agreement with Russian President Vladimir Putin following the Russian intervention in Syria that allowed Israel to continue attacks against weapon transfers to Hizballah in southern Syria without Russian interference. ${ }^{69} \mathrm{~A}$ Western analyst similarly argued that, in his June 2016 visit to Moscow, Netanyahu "made it clear to the Russian leader that Israel had two 'red lines' in Syria that could not be crossed—preventing Iran and Hizbollah from creating another front against Israel near the Golan Heights, similar to the one in South Lebanon, and preventing Iran and Syria from sending sophisticated arms to Hizbollah that could be used to threaten Israel." ${ }^{70}$ While Israeli concerns about weapon transfers to Hizballah is not new, in the past, the primary concern was Iranian activity and support for Hizballah in Lebanon and transfers of weapons through Iran to Syria. But now with the Russian military intervention in Syria, the potential for Russian advanced weaponry to reach Hizballah through Iran is an additional worry for Israeli security planners.

Despite widespread concern about Iran's growing role in Syria, Israeli security analysts are less alarmed about Sunni extremist groups fighting on Israel's northern border. An Islamic State branch, the Yarmouk Martyrs Brigade, controls a nine-mile strip of land in the southern Golan, along the border between Israel and Syria, but the group has been busy fighting the al-Qaeda-affiliated
Jabhat al-Nusra opposition forces to the north. ${ }^{71}$ Israeli security analysts recognize that these Islamist groups could eventually turn their sights on Israel, but for the time being, they are considered a lesser threat compared with Iran's and Hizballah's presence in Syria. As one former military official noted, "the jihadis haven't fired one bullet into Israel" and openly admit that Israel is too strong for them to deal with now. ${ }^{72}$ The former head of the IDF's military intelligence unit, Yadlin, similarly argued: "While ISIS is not to be ignored, our strategic priority must be handling the Tehran-Baghdad-Damascus-Beirut axis first." ${ }^{\text {”3 }}$

One Israeli official complained that the United States is "too focused on ISIS," which the official ranked as a third-order threat compared with Iran and Hizballah, noting Iran's role in radicalizing Sunnis rather than acting as a balancer against ISIS. This official also suggested that, while everything looks "kosher" to the United States following the nuclear agreement, Israel is left with the implications of Iran's broader regional behavior, particularly on Israel's northern border. ${ }^{74}$ And while Israel appears to have worked out a tactical arrangement with the Russians to "de-conflict" their operations in Syria, officials worry that Russia cannot be counted on to restrain Iran's role in Syria given Russia's cooperation in support of the Assad government. ${ }^{75}$ Some former intelligence officials are less alarmed, assessing that Hizballah is significantly weakened from its costly intervention in Syria and that both Iran and Hizballah are constrained by Russia's involvement in the country. ${ }^{76}$

These differing threat assessments do not ultimately challenge the fundamental shift in Israel's post-deal Iran policies from a focus on the nuclear issue to concerns about Iran's broader regional activities, particularly its role in Syria. 
Increasing Discussion About Converging Interests with the Gulf Cooperation Council but Limited Policy Changes

It is no secret that both Israel and the Arab Gulf states share similar threat assessments of Iran. While the Gulf Cooperation Council (GCC) states were less vocal in their opposition to the nuclear agreement and tepidly supported it once finalized, they share Israeli concerns that the agreement will embolden Iran and increase its regional meddling. The GCC states also share Israeli concerns about enhanced U.S.-Iranian engagement, because they also assess that the agreement will legitimize Iran in the international community. ${ }^{77}$ Israel and the GCC states share other regional interests beyond Iran, such as supporting President Abdel Fattah el-Sisi in Egypt and bolstering Jordanian stability. Former Israeli and Saudi officials have even appeared together publicly on panels in recent years to discuss areas of common interest, discussions that previously only took place behind closed doors. ${ }^{78}$ Behind-the-scenes diplomatic exchanges and business dealings are also believed to be expanding between Israel and some Arab Gulf states. ${ }^{79}$

But despite such developments, there are few signs that the JCPOA has served as an impetus for more-robust and more-visible cooperation between Israel and the Arab Gulf. A major constraint on the Arab side to greater normalization is the continued IsraeliPalestinian conflict; without progress on this front, more-expansive diplomatic and economic ties with Israel are unlikely. For Israel, "geographic necessity" makes Egypt and Jordan—not the Arab Gulf-the "bread and butter" for Israel's partnerships in the Sunni world. ${ }^{80}$ As one Israeli official observed, while the Saudis might take actions that benefit Israel, such as distancing Sudan from Iran and assisting Egypt, they are doing it for their own reasons and have their own priorities: "This is not a coordinated policy." ${ }^{81}$ For Israel, the Gulf is ultimately tangential to core security interests. Moreover, popular sentiment in Israel continues to harbor negative views of key Gulf states, such as Saudi Arabia, with only 10 percent of Israeli Jews holding favorable views (certainly better than the 0 percent favorability toward Iran, but hardly a strong endorsement for warming ties). ${ }^{82}$

\section{A Direct Military Strike Against Iran's Nuclear Facilities Is Largely off the Table, but Military Conflict with Iran Is Still Possible}

Up until late 2012, an Israeli military strike against Iran's nuclear facilities seemed plausible. ${ }^{83}$ According to a former Israeli defense official, it was not clear to senior Israeli defense officials whether Israeli political leaders were serious about using a military option or were only preparing the military option to increase pressure on the Americans to address the Iranian nuclear problem. ${ }^{84}$ Whether the Israeli military was preparing military options for actual use or merely for political influence, the strategy of focusing on the military option became obsolete by late 2012 and early 2013, when it became clear that the diplomatic track with Iran was serious. ${ }^{85}$

After the JCOPA, a few Israeli analysts, such as Efraim Inbar, asserted that an Israeli military strike on Iran was more likely "before the US puts the brakes on military supplies to the Israeli army." ${ }^{" 66}$ But such assessments are in the minority among Israel's security establishment. The prevailing view among Israeli analysts is that the military option is now off the table as long as Iran is implementing the JCPOA. One analysis explained, "Now, 
The prevailing view among Israeli analysts is that the military option is now off the table as long as Iran is implementing the JCPOA.

with the entire international community behind the agreement, it's unlikely that there is even one person in the top ranks of the defense establishment-including the chief of the Mossad, the director of the Shin Bet security service and the commander of the air force-who supports an attack on Iran. ${ }^{\prime 77}$ A former military official similarly asserted that as long as Iran is implementing the agreement, options to launch military strikes on nuclear facilities (Fordow, Natanz, and Arak) "are gone." ${ }^{88}$

That said, a military conflict between Iran and Israel is still possible, but it is less likely to be the result of a deliberate Israeli attack on Iran's nuclear facilities than from an unintended escalation between Israel and Iran in southern Syria (the killing of the Iranian general in the Golan is an example of an incident that could lead to direct military confrontation). As discussed, the presence of Iranian forces in the Syrian Golan and the transfer of sophisticated weaponry to Hizballah are redlines for Israel, and Israel has already demonstrated its willingness to strike inside Syria to demonstrate its resolve. To date, Iran and Hizballah have not retaliated for such Israeli actions, keeping their focus on the Syrian battlefield, where they are fighting anti-Assad forces. Many analysts believe that Hizballah is suffering too many losses in Syria to risk a renewed confrontation with Israel. However, dynamics in Syria (or among Iranian and Hizballah's leadership) could change, altering calculations about the value of attacking Israel. Miscalculations are also possible given the complexity of the battlefield in southern Syria, increasing the potential for military escalation on the Golan border even if unintended.

Israel might also consider more-covert actions, such as offensive cyber campaigns, to weaken Iran's nuclear and military capabilities (particularly its missile development) during the implementation of the JCPOA.$^{89}$ Indeed, in October 2015, this is how the head of Israel's Directorate of Military Intelligence Herzl "Hertzi" Halevi responded to a question about whether Israel will go to war with Iran in the next decade: "We are already at war with Iran. It's a technological war; our engineers are fighting theirs, and this fighting will only grow in the future." ${ }^{90}$ Such covert activities also risk escalation that could spill over to more-conventional military confrontations between Iran and Israel.

\section{Israeli Efforts Are More Likely to Focus on Nonkinetic} Areas, Exposing Iranian Violations and Sanctioning Iran's Nonnuclear Activities

While many Israeli officials and analysts expect Iranian compliance with the JCPOA, they still worry about Iran trying to test the limits of the agreement and the West's resolve to confront Iran. Israel will consequently feel the need to continue exposing what it views as Iranian violations. As one former official put it, "Bibi's strategy moving forward will be to remain the pain in the neck" that keeps up pressure on Iran in the nonnuclear areas. ${ }^{91}$ Netanyahu made it clear after the JCPOA implementation day in January 2016 that "Israel would strengthen its defenses, increase its intelligence resources and 'warn of any violation' of the agreement." ${ }^{2}$ Israeli officials are particularly worried that "Iran will 
play in the gray areas" (e.g., missile development, the transferring of weapons and funding to terrorist groups) and will not be confronted because of the U.S. investment in the agreement. ${ }^{93}$ Israel officials are also concerned that the United States and Europe's focus on ISIS will distract them from Iran and even lead Western powers to view Iran as a partner rather than as a regional troublemaker. ${ }^{94}$ Israelis worry that they are being abandoned as the United States focuses on ISIS and edges toward partnerships with Iran and the Shi'a. ${ }^{95}$

Such perceptions would be strongly disputed by many U.S. policymakers and analysts given the continued friction and mistrust between the United States and Iran. But such perceptions shape the Israeli approach, which is focused on reminding the world of Iran's nefarious activities, both at home and throughout the region. Consequently, continuing to encourage the enforcement and creation of new nonnuclear sanctions in the U.S. Congress will be a fundamental element of Israel's post-deal strategy toward Iran. Israel is likely to support measures that will make it difficult for Iran to reap the benefits of sanction relief and keep up the pressure in key nonnuclear areas, such as missile testing and human rights abuses. Congress is likely to be a receptive audience to this approach; many members were as opposed to the JCPOA as Israel was, and even those members who supported the JCPOA want to demonstrate that the agreement is not eroding broader U.S. containment policies toward Iran. Both nominees for the 2016 presidential election have also expressed a more confrontational approach to Iran than the Obama administration has, even though former Secretary of State Hillary Clinton supported the Iran agreement.

\section{Israel Also Continues to Prepare for the Future}

Although Iran claims not to harbor intentions for nuclear weapons and is committed to a limited civilian nuclear program under the JCPOA (in addition to being a party to the NPT), the prevailing Israeli assessment expects Iran to eventually seek to acquire nuclear weapons or at least a weapon capability. It is thus not surprising that Israel is already demonstrating an interest in bolstering its own deterrence capabilities in the post-deal environment.

While Israel continues to pursue an official policy of nuclear ambiguity, Israeli journalists and analysts have reported on developments that appear to support the strengthening of Israel's second-strike capabilities designed to enhance deterrence against potential nuclear adversaries. One Israeli analyst noted an uncommon photographed visit by the Israeli prime minister following the nuclear agreement to a ceremony celebrating the acquisition of a new submarine, a clear signal demonstrating Israel's deterrence capabilities. ${ }^{96}$

Another key element of Israel's deterrence strategy is its special security relationship with the United States. There is increasing concern in Israel's security community about the maintenance of Israel's Qualitative Military Edge because of the growth of Iran's local defense industry - particularly in the areas of unmanned aerial vehicles, cyber, precision bombs, and missiles - and because Iran has acquired advanced air defense capabilities from Russia and China. ${ }^{97}$ Post-JCPOA agreements between the United States and Arab Gulf states, including the authorization of more than $\$ 33$ billion in arms sales to the six GCC states in March 2016, ${ }^{98}$ are also raising concern in Israel, although shared alarm over Iran has reduced Israel's opposition to U.S. arms deals with Sunni Arab states in recent years. 


\section{Israeli leaders still perceive Iran as Israel's primary security challenge, but the focus has shifted from Iran as a nuclear problem to Iran as a regional problem.}

Consequently, despite Israeli concerns that the JCPOA represented a reduced U.S. commitment to Israeli security, the JCPOA provided a new impetus for Israel to enhance its security relationship with the United States. Following the nuclear agreement, the United States and Israel began negotiations for renewing their memorandum of understanding on security assistance for another ten years, although reports suggest tension in the negotiations as friction lingers from the rift between Obama and Netanyahu over the nuclear deal. ${ }^{99}$ Nonetheless, reports indicate that the aid package would amount to a significant increase in U.S. security assistance to Israel (already the single largest recipient of U.S. foreign aid) to respond to concerns in Israel and in the U.S. Congress about the nuclear deal endangering Israeli security. ${ }^{100}$ Reports also suggest Israel is interested in not only increased aid but also bolstering of its qualitative military advantage regionally with an eye toward Iran, including requests for larger numbers of F-35's, bunker-penetrating bombs, and increased support for missile defense systems. ${ }^{101}$

\section{Conclusion}

Given the intensity of the debate over the final nuclear agreement with Iran, it is striking how quickly the conversation in Israel changed from the Iran nuclear threat to the conflict in Syria and growing tensions with Palestinians. Israeli leaders still perceive Iran as Israel's primary security challenge, but the focus has shifted from Iran as a nuclear problem to Iran as a regional problem. Of particu- lar concern are Iran's nonnuclear activities, especially its continued missile development, its growing presence in the Syrian Golan, and its continued support to Hizballah. Indeed, Israel's redlines vis-à-vis Iran appear to be preventing a permanent Iranian presence on Israel's border with Syria, as well as continued opposition to the shipment of advanced weaponry to Hizballah in Syria.

The common view among political leaders and the Israeli security establishment is that the nuclear agreement has "unleashed" Iran, leading to increased destabilizing regional activities that threaten Israeli security. And while many Israeli analysts believe that Iran will comply with the agreement-and some even see benefits to Israel from the nuclear rollbacks that the agreement requires - they are nonetheless concerned about Iran's efforts to enhance its conventional capabilities in the near term and, in the long term, its future nuclear intentions once key elements of the agreement expire in ten to fifteen years.

Consequently, Israeli policies following the agreement are focused on exposing potential Iranian violations of the JCPOA, as well as on addressing nonnuclear activities of concern, combined with sanction enforcement in these nonnuclear arenas (missile development and testing, terrorist links, and human rights abuses). Israel is also taking steps to prepare for a future when Iran might emerge as a nuclear power, bolstering deterrence capabilities, and reaffirming its security relationship with the United States. Israel does not appear likely to attack Iran's nuclear facilities during the 
JCPOA's implementation period, as long as Iran is adhering to the agreement. But escalation between Israel and Iran on the Syrian border is possible, risking a future military conflict that might not be intentional.

Thus, while the nuclear agreement removed a serious source of instability in the region by addressing Iran's ability to weaponize its nuclear program for at least the foreseeable future, the agreement has not removed other risks to regional stability related to Iran. In fact, perceptions of the Iranian threat in Israel and other Middle Eastern states have only increased following the nuclear agreement, motivating Iran's neighbors to find other ways to counter its influence in the region. Some of these measures have already involved the escalation of existing regional conflicts, such as in Syria and Yemen. But the potential for new military conflicts, and particularly an Iranian-Israeli escalation, is serious as long as Iran and Hizballah continue to actively operate in southern Syria.

Such post-deal dangers have implications for U.S. policy. ${ }^{102}$ It is difficult to determine whether the rift in U.S.-Israeli relations over the nuclear agreement will result in longer-term damage to U.S.Israeli relations. Israel's reluctance to quickly conclude a generous aid package from the United States under Obama suggests some continued friction in the relationship. ${ }^{103}$ That said, support for Israel is overwhelming in the U.S. Congress, and both presidential nominees have indicated unequivocal support for Israel and a strong U.S.-Israeli relationship, suggesting that the long-term impact of Netanyahu's perceived partisan approach over the Iran deal is likely to be minimal. (Israel's approach to the Palestinians is likely to have more impact on views in Congress and on other U.S. leaders than Israel's past positions on the JCPOA.)

While U.S.-Israeli relations are likely to remain robust despite the rift over the nuclear agreement, there are a number of steps the United States can take to minimize future misunderstandings and prevent unwanted Israeli actions that could challenge U.S. regional interests. For example, U.S. officials would be wise to consider Israeli redlines in future negotiations over a post-conflict settlement in Syria, particularly in discussions with Russia. Although a permanent end to the conflict in Syria unfortunately does not appear imminent, a final agreement that prevents Iran or Hizballah from establishing a permanent Iranian presence on Israel's border could avoid future instability.

Enhanced and broader communication channels between the United States and Israel will also be important, particularly after the U.S. presidential election in November 2016. To avoid misunderstandings about what might constitute a violation of the JCPOA (and uncoordinated military or covert actions by Israel), the United States and Israel should institute clear understandings about what would constitute a violation and what the range of acceptable responses might be. Over the coming decade, the United States could share information about Iran's JCPOA compliance or offer Israeli officials regular intelligence briefings on the

\section{While the nuclear agreement removed a serious source of instability in the region by addressing Iran's ability to weaponize its nuclear program for at least the foreseeable future, the agreement has not removed other risks to regional stability related to Iran.}


Enhanced communications would...

\section{provide an opportunity for the United}

States to explain its assessment of regional developments and actions by Israel that might be helpful or unhelpful for advancing U.S. interests.

state of Iranian nonnuclear programs that concern Israel (particularly Iran's missile program). The next U.S. president could also create a JCPOA-expiration working group to plan for the JCPOA's termination, consulting with Israelis early in the process. This would allow Israeli decisionmakers to feel that that their concerns were being heard while U.S. policy was still being formulated.

While bilateral military and intelligence cooperation is already strong, increased and regular engagement among political leaders, not just technical experts, could further strengthen Israel's confidence in the agreement and allow U.S. policymakers to convey core U.S. regional interests, preventing misunderstandings about U.S. policy in the region. ${ }^{104}$ Israeli leaders have expressed concern that the agreement is so important to the United States that its government has a "don't bother us with the facts" mentality, but U.S. administration officials continue to argue that the agreement makes Israel safer by removing a nuclear context to Iran's expected regional activities of concern. But many believe that more-institutionalized and more-frequent channels for U.S.Israeli communication on the agreement would minimize this distrust. ${ }^{105}$ Such discussions should also include a broader dialogue on regional challenges beyond the JCPOA's implementation to maximize understanding and trust that might prevent unwanted escalation with Iran. Enhanced communications would also provide an opportunity for the United States to explain its assessment of regional developments and actions by Israel that might be helpful or unhelpful for advancing U.S. interests. 


\section{Notes}

${ }^{1}$ For an analysis of Israeli responses to the interim nuclear agreement, see Dalia Dassa Kaye and Jeffrey Martini, The Days After a Deal with Iran: Regional Responses to a Final Nuclear Agreement, Santa Monica, Calif.: RAND Corporation, PE-122-RC, 2014, http://www.rand.org/pubs/perspectives/PE122.html.

${ }^{2}$ Israel also found out about the Oman channel through intelligence sources rather than directly from the United States, which may have increased resentment toward the U.S. approach to Iran and the nuclear negotiations.

${ }^{3}$ For example, Amos Yadlin was one of the most vocal Israeli security analysts arguing for a more concrete definition of what an acceptable deal for Israel could look like that acknowledged that some limited Iranian nuclear infrastructure might remain. See Amos Yadlin and Avner Golov, "A Nuclear Deal Israel Could Live With," Foreign Affairs, March 30, 2015, https://www.foreignaffairs.com/ articles/iran/2015-03-30/nuclear-deal-israel-could-live.

${ }^{4}$ One former defense official suggested that Netanyahu was not interested in the details of the deal, because, in the official's view, the deal itself was wrong so the details did not matter. From April 2013, when U.S. negotiations with Iran in Oman became serious, defense officials advised decisionmakers in Israel to prepare for an agreement. But decisionmakers did not accept this assessment because they did not think that a good deal was possible with Iran. Interview with former Israeli defense official, Tel Aviv, January 17, 2016.

${ }^{5}$ For official statements and the full text of the agreement, see U.S. Department of State, "Joint Comprehensive Plan of Action," web page, undated

http://www.state.gov/e/eb/tfs/spi/iran/jcpoa/.

${ }^{6}$ See Tamar Pileggi and Jonathan Beck, "Netanyahu Calls Iran Deal 'Historic Mistake for World," Times of Israel, July 14, 2015,

http://www.timesofisrael.com/

netanyahu-calls-iran-deal-historic-mistake-for-world/.

${ }^{7}$ While Iran's NPT obligations permanently restrict the country from weaponizing its civilian nuclear program, most Israelis do not believe that NPT restrictions will ultimately prevent Iran's nuclear ambitions, because it allows for continued nuclear enrichment. Such concerns, and Iran's previous violations of the NPT, were the basis for far more extensive rollbacks and restrictions on Iran's enrichment levels and verification of Iran's civilian program in the JCPOA.

${ }^{8}$ Barak Ravid, "Netanyahu: Iran Nuclear Deal Makes World Much More Dangerous, Israel Not Bound by It," Haaretz, July 14, 2015, http://www.haaretz.com/ israel-news/1.665821.
${ }^{9}$ Moran Azulay, "Negotiators Reach Historic Nuclear Agreement with Iran," Ynet, July 14, 2015, http://www.ynetnews.com/articles/0,7340,L-4679591,00.html.

10 "Israeli Leaders, Some Jewish Groups Condemn Final Iran Nuclear Deal," Jewish Telegraphic Agency, July 14, 2015,

http://www.jta.org/2015/07/14/news-opinion/united-states/ israeli-leaders-jewish-groups-condemn-final-iran-nuclear-deal-2.

${ }^{11}$ For an overview of some of the common Israeli objections to the agreement, see Efraim Inbar, "Six Strikes Against the Nuclear Deal with Iran," BESA Center Perspectives Paper No. 301, Ramat Gan, Israel: Begin-Sadat Center for Strategic Studies, July 15, 2015,

http://besacenter.org/perspectives-papers/

six-strikes-against-the-nuclear-deal-with-iran/.

${ }^{12}$ Author interview with Israeli official, Jerusalem, January 14, 2016.

${ }^{13}$ One Israeli official expressed concern not only about Iranian support to groups like Hizballah but also about what he asserted was renewed Iranian support for Hamas's military wing, because it was being "squeezed" by Egypt and receiving insufficient funding from Qatar. Author interview with Israeli official, Jerusalem, January 14, 2016.

${ }^{14} \mathrm{Gold}$ argued Iran has a "terrorist presence in some 30 countries on five continents" and is developing "space-lift capable rockets-which aren't just for putting mice into orbit, but are ultimately for giving Iran intercontinental ballistic missile capability." See Raphael Ahren, "Battle to Thwart Iran Nuke Deal Not Over, Foreign Ministry Chief Vows," Times of Israel, July 13, 2015,

http://www.timesofisrael.com/

battle-to-thwart-the-iran-nuke-deal-is-not-over-foreign-ministry-chief-vows/.

${ }^{15}$ Gilad made this assertion in a Hebrew interview with $N R G$ and Israel Defense Magazine. See "Ha’aluf Gilad: "Be-2016 Abu Mazen Yisahef Le'imut Mulenu" ["Major General Gilad: In 2016 Abu Mazen Will Be Dragged to a Conflict with Us"], $N R G$, December 25, 2015, http://www.nrg.co.il/online/1/

ART2/744/466.html.

${ }^{16}$ Raphael Ahren, "Battle to Thwart Iran Nuke Deal Not Over, Foreign Ministry Chief Vows," Times of Israel, July 13, 2015,

http://www.timesofisrael.com/

battle-to-thwart-the-iran-nuke-deal-is-not-over-foreign-ministry-chief-vows/.

${ }^{17}$ Raphael Ahren, Battle to Thwart Iran Nuke Deal Not Over, Foreign Ministry Chief Vows," Times of Israel, July 13, 2015

http://www.timesofisrael.com/

battle-to-thwart-the-iran-nuke-deal-is-not-over-foreign-ministry-chief-vows/. 
${ }^{18}$ Under the terms of the Iran Nuclear Agreement Review Act of 2015 (Public Law 114-17), Congress had sixty days to review any nuclear agreement with Iran. Resolutions of disapproval for the agreement would have had to garner enough votes in both the House and the Senate to override a presidential veto. In the end, the resolution of disapproval did not have enough votes under Senate rules to proceed to the floor for a final vote.

${ }^{19}$ Karoun Demirjian and Carol Morello, "How AIPAC Lost the Iran Deal Fight," Washington Post, September 3, 2015, https://www.washingtonpost.com/news/ powerpost/wp/2015/09/03/how-aipac-lost-the-iran-deal-fight/.

${ }^{20}$ See the White House's announcement and required steps at this stage of the agreement: Office of the Press Secretary, White House, "Statement by the President on the Adoption of the Joint Comprehensive Plan of Action," October 18, 2015 ,

https://www.whitehouse.gov/the-press-office/2015/10/18/

statement-president-adoption-joint-comprehensive-plan-action.

${ }^{21}$ See the U.S. Department of the Treasury's statement outlining changes in sanctions policies toward Iran following the implementation of the agreement: U.S. Department of the Treasury, "JCPOA Implementation: Implementation Day Statement," January 16, 2016,

https://www.treasury.gov/resource-center/sanctions/OFAC-Enforcement/Pages/ jcpoa_implementation.aspx.

${ }^{22}$ Akiva Eldar, "Why Bibi Is Personally Responsible for Iran Policy Failure," Al-Monitor, July 14, 2015,

http://www.al-monitor.com/pulse/originals/2015/07/

iran-agreement-powers-netanyahu-bush-clinton-obama-israel.html\#.

${ }^{23}$ Yossi Alpher, "The Iran Nuclear Deal and Its Aftermath," APN, July 20, 2015, https://peacenow.org/entry.php?id=12874\#.V1Cv62M4Tdk.

${ }^{24}$ Marissa Newman, "Liberman: Netanyahu Incapable of Stopping the Iran Deal," Times of Israel, July 24, 2015,

http://www.timesofisrael.com/

liberman-netanyahu-incapable-of-stopping-the-iran-deal/.

${ }^{25}$ Yaakov Lappin, "Eiland Calls for Discreet Talks with US to Ensure Long-Term Obligations," Jerusalem Post, July 15, 2015,

http://www.jpost.com/Israel-News/Politics-And-Diplomacy/

Eiland-calls-for-discreet-talks-with-DC-to-ensure-long-term-obligations- 409006.

${ }^{26}$ Haim Ramon, "Bibi’s Nuclear March of Folly," Ynet, July 29, 2015,

http://www.ynetnews.com/articles/0,7340,L-4684949,00.html.
${ }^{27}$ Quoted in Hezki Baruch, "Livni Blames Netanyahu for Congress Support of Iran Deal," Arutz Sheva, September 3, 2015,

http://www.israelnationalnews.com/News/News.aspx/ 200238\#.V1DLCWM4Tdk.

${ }^{28}$ See David Menashri, “The Nuclear Accord with Iran: The Day After," ACIS Iran Pulse, No. 75, July 30, 2015,

http://humanities1.tau.ac.il/iranian/en/ staff-en/10-iran-pulse-en/324-iranpulseno75.

${ }^{29}$ See Dalia Dassa Kaye, "New Israeli Government, New Position on Iran?" Newsweek, March 17, 2015, http://www.newsweek.com/ new-israeli-government-new-position-iran-314254.

${ }^{30}$ Quoted in Jeffrey Goldberg, "Israeli Opposition Leader: Iran Deal Will Bring Chaos to the Middle East," The Atlantic, July 16, 2015, http://www.theatlantic.com/international/archive/2015/07/ israel-isaac-herzog-iran-nuclear-deal/398705/.

${ }^{31}$ Mazal Mualem, "Former Israeli Minister Calls Removal of Iran Sanctions a 'Black Day," Al-Monitor, January 18, 2016,

http://www.al-monitor.com/pulse/originals/2016/01/

ephraim-sneh-deputy-defense-minister-iran-nuclear-agreement.html.

${ }^{32}$ The organization's name transliterates from Arabic as al-Dawlah al-Islamiyah fi al-'Iraq wa al-Sham (abbreviated as Da'ish or DAESH). In the West, it is commonly referred to as the Islamic State of Iraq and the Levant (ISIL), the Islamic State of Iraq and Syria, the Islamic State of Iraq and the Sham (both abbreviated as ISIS), or simply as the Islamic State (IS). Arguments abound as to which is the most accurate translation, but here we refer to the group as ISIS.

${ }^{33}$ Mazal Mualem, "Former Israeli Minister Calls Removal of Iran Sanctions a 'Black Day,” Al-Monitor, January 18, 2016, http://www.al-monitor.com/pulse/originals/2016/01/ ephraim-sneh-deputy-defense-minister-iran-nuclear-agreement.html.

${ }^{34}$ Mazal Mualem, "Former Israeli Minister Calls Removal of Iran Sanctions a 'Black Day," Al-Monitor, January 18, 2016,

http://www.al-monitor.com/pulse/originals/2016/01/

ephraim-sneh-deputy-defense-minister-iran-nuclear-agreement.html.

${ }^{35}$ Several former Israeli officials, as well as analysts, argued in interviews with the author that the prime minister has not paid any significant political price for his stance on the Iran agreement. 
${ }^{36}$ Ben Caspit, "New Mossad Chief Brings Touch of Bond, Lots of Reality to the Job," Al-Monitor, January 11, 2016,

http://www.al-monitor.com/pulse/originals/2016/01/israel-mossad-yossi-cohennew-chief-mideast-chaos-challenge.html.

${ }^{37}$ Benjamin Gantz, "Israeli National Security in a Changing Regional Environment," speech at the eighth annual Zeev Schiff Memorial Lecture on Israeli National Security, The Washington Institute for Near East Policy, Washington, D.C., September 25, 2015, http://www.washingtoninstitute.org/policy-analysis/ view/israeli-national-security-in-a-changing-regional-environment.

${ }^{38}$ Benjamin Gantz, "Israeli National Security in a Changing Regional Environment," speech at the eighth annual Zeev Schiff Memorial Lecture on Israeli National Security, The Washington Institute for Near East Policy, Washington, D.C., September 25, 2015, http://www.washingtoninstitute.org/policy-analysis/ view/israeli-national-security-in-a-changing-regional-environment.

${ }^{39}$ Author interview with former Israeli defense official, Tel Aviv, January 17, 2016.

${ }^{40}$ For analysis of Eizenkot's speech, see J. J. Goldberg, "Israel's Top General Praises Iran Deal as 'Strategic Turning Point' in Slap at Bibi,” Forward, January 26, 2016, http://forward.com/opinion/331714/israels-top-general-praises-iran-deal-as-strategic-turning-point-in-slap-at/. For a video of the speech, see "9th Annual International Conference: Changing Rules of the Game?” Institute for National Security Studies, undated, http://www.inss.org.il/index.aspx?id=4480\&eventid=10709.

${ }^{41}$ See Graham Allison, "Is Iran Still Israel's Top Threat?” The Atlantic,

March 8, 2016, http:/www.theatlantic.com/international/archive/2016/03/ iran-nuclear-deal-israel/472767/.

${ }^{42}$ One former defense official argued that there was no better alternative to postponing an Iranian bomb for five to ten years, and he did not think that there was a better deal than what was agreed to in the JCPOA. Author interview with former defense official, Tel Aviv, January 17, 2016.

${ }^{43}$ Amos Yadlin, "Following the Problematic Nuclear Agreement: Scenarios and Policy Recommendations," INSS Insight No. 722, Tel Aviv: Institute for National Security Studies, July 20, 2015, http://www.inss.org.il/?id=4538\&articleid=10100

${ }^{44}$ PBS Newshour, "Expecting Iran to Cheat Is Why We Need This Deal, Says Former Mossad Chief,” interview with Efraim Halevy, August 21, 2015, http://www.pbs.org/newshour/bb/

expecting-iran-try-cheat-need-deal-says-former-mossad-chief/.
${ }^{45}$ See, for example, Hardin Lang and Shlomo Brom, "6 Biggest Myths About the Iran Nuclear Deal,” The National Interest, July 29, 2015,

http://nationalinterest.org/feature/

6-biggest-myths-about-the-iran-nuclear-deal-13443; Yossi Alpher, "The Iran Nuclear Deal and Its Aftermath,” APN, July 20, 2015, https://peacenow.org/ entry.php?id=12874\#.V1Cv62M4Tdk. See Isaac Ben-Israel's, chairman of the Israeli Space Agency, arguments in favor of the agreement in Mazal Mualem, “Israeli Media Drowns Out Pro-Iran-Deal Voices," Al-Monitor, July 21, 2015, http://www.al-monitor.com/pulse/originals/2015/07/ netanyahu-herzog-lapid-iran-nuclear-deal-ben-israel-expert.html.

${ }^{46}$ Author interview with Israeli analyst, Tel Aviv, January 13, 2016.

${ }^{47}$ Chaim Levinson, “Israel's Nuclear Advisory Panel Endorses Iran Deal,” Haaretz, October 22, 2015, http://www.haaretz.com/israel-news/.premium-1.681918.

${ }^{48}$ Author interview with former senior Israeli military official, Tel Aviv, January 13, 2016.

${ }^{49}$ Author interview with former senior Israeli military official, Tel Aviv, January 13, 2016.

${ }^{50}$ Ron Tira and Yoel Guzansky, "Is Iran in Strategic Equilibrium?" The Institute for National Security Studies, Strategic Assessment, Vol. 18, No. 4, January 2016 p. 12, http://www.inss.org.il/uploadImages/systemFiles/ adkan18_4ENG3_Tira-Guzansky.pdf.

${ }^{51}$ Such views were expressed in multiple author interviews with Israeli analysts and former officials in January 2016.

${ }^{52}$ For an Israeli assessment of Iran's likely compliance with the JCPOA in order to reap its strategic benefits, see Oded Brosh, "IAEA 26 February 2016 Iran Inspection Report Summary,” IDC Herzilya, February 29, 2016, http://www.herzliyaconference.org/_Uploads/ dbsAttachedFiles/IAEAFebruary2016IranInspectionReport.pdf.

${ }^{53}$ Yaakov Amidror, "The Vienna Accord Only Postpones Confrontation with Iran,” Ramat Gan: Begin-Sadat Center for Strategic Studies, BESA Center Perspective Papers No. 303, August 5, 2015, http://besacenter.org/perspectives-papers/ after-vienna-three-scenarios-for-likely-confrontation-with-iran/. 
${ }^{54}$ Landau quoted in Yaacov Lapin, "A Deal with Gaping Failures," Jerusalem Post, July 18, 2015, http://www.jpost.com/Middle-East/

A-deal-with-gaping-failures-409287. While noting some positive nuclear rollbacks in the agreement, Ariel E. Levite (a former deputy general at the Israeli Atomic Energy Commission) similarly expressed concern over several elements of the agreement, including continued research and development on advanced centrifuges and particularly the mechanisms for verifying Iranian compliance and the reimposition of sanctions should Iran violate the agreement. See Ariel (Eli) Levite, "The Good, the Bad and the Ugly Nuclear Agreement," Haaretz, July 17, 2015, http://carnegieendowment.org/2015/07/17/ good-bad-and-ugly-nuclear-agreement/idjg.

${ }^{55}$ See Emily B. Landau, "What 29 Top US Scientists Don't Know," Times of Israel, August 10, 2015, http://blogs.timesofisrael.com/

what-29-top-us-scientists-dont-know/. As Landau says, "[T]here is a need to consider the history of dealing with Iran. . . . Iran has shown its determination not only to hold on to its vast nuclear infrastructure and breakout capability, but continues its highly aggressive attitude toward the US and the Middle East ... Iran has over the years perfected tactics of playing for time."

${ }^{56}$ Phone interview with former Israeli official, January 22, 2016.

${ }^{57} \mathrm{~A}$ former Israeli defense official suggested that the predominant IDF and Mossad assessment (and of most security professionals in Israel) is that the JCPOA has pushed the nuclear issue off for at least ten years. Author interview with former Israeli defense official, Tel Aviv, January 17, 2016.

${ }^{58}$ Barbara Opall-Rome, "Israeli DM: Iran Deal Is Done, Time to Look Ahead," Defense News, October 28, 2015,

http://www.defensenews.com/story/defense/policy-budget/leaders/2015/10/28/ israeli-dm-iran-deal-done-time-look-ahead/74754218/.

${ }^{59}$ See Amos Harel, "Israel's Evolving Military: The IDF Adapts to New Threats," Foreign Affairs, June 8, 2016,

https://www.foreignaffairs.com/articles/israel/2016-06-08/

israel-s-evolving-military.

${ }^{60}$ Author interview with Israeli analyst, Tel Aviv, January 13, 2016.

${ }^{61}$ For an overview of Israel's interests in Syria—particularly its approach to managing Russian and Iranian influence and its concerns about the presence of Hizballah, ISIS, and other extremist groups engaged in the Syrian conflict-see Larry Hanauer, Israel's Interests and Options in Syria, Santa Monica, Calif.: RAND Corporation, PE-185-DIA, 2016, http://www.rand.org/pubs/perspectives/ PE185.html.
${ }^{62}$ Author interview with former military official, Tel Aviv, January 13, 2016. In this analyst's view, Russian President Vladimir Putin would not have cooperated with Iran's IRGC head in Syria in the absence of the nuclear agreement.

${ }^{63}$ Author interview with Israeli official, Jerusalem, January 14, 2016. Previous U.S. government estimates of Iranian assistance to Hizballah are in the range of $\$ 100$ to $\$ 200$ million per year. For details on Iran's support for Hamas and Hizballah, see Kenneth Katzman, Iran's Foreign Policy, Washington, D.C.: Congressional Research Service, January 29, 2016, especially pp. 15-17, https://www.fas.org/sgp/ crs/mideast/R44017.pdf.

${ }^{64}$ For an analysis piece outlining these views, see Meir Javedanfar, "Israel's Next Worry," Chatham House, The World Today, December 2015, Vol. 71, No. 6, https://www.chathamhouse.org/publication/twt/ middle-east-2016-israel-s-next-worry.

${ }^{65}$ See Anne Barnard, "Iran Confirms Israeli Airstrike in Southern Syria Killed One of Its Generals," New York Times, January 19, 2015, http://www.nytimes.com/2015/01/20/world/middleeast/ iran-says-one-of-its-generals-was-killed-in-israeli-strike-in-syria.html?_r=0.

${ }^{66}$ Author interview with former official, Tel Aviv, January 13, 2016.

${ }^{67}$ Author interview with Israeli official, Jerusalem, January 14, 2016. Another Israeli analyst sees Israel's primary postagreement goal as protecting the Golan border from Iranian attacks. Author interview with Israeli analyst, Jerusalem, January 14, 2016.

${ }^{68}$ Author interview with Israeli officials, Jerusalem, January 14, 2016.

${ }^{69}$ Author interview with Israeli analyst, Tel Aviv, January 13, 2016. A former senior Israeli intelligence official also suggested that Russia is not preventing Israeli military action against Hizballah and Iran in the southern-border area (author interview with former senior Israeli intelligence official, Tel Aviv, January 17,2016$)$.

${ }^{70}$ Robert O. Freedman, "Russia, Iran and Israel: Putin's Strange Middle Eastern Diplomatic Front," New Delhi: Middle East Institute New Delhi, commentary, No. 381, July 18, 2016, http://mei.org.in/front/cms/ publicationsDetail.php?id=MTE3MA==.

${ }^{71}$ Ben Caspit, "New Mossad Chief Brings Touch of Bond, Lots of Reality to the Job," Al-Monitor, January 11, 2016,

http://www.al-monitor.com/pulse/originals/2016/01/

israel-mossad-yossi-cohen-new-chief-mideast-chaos-challenge.html.

${ }^{72}$ Author interview with former senior military official, Tel Aviv, January 13, 2016. 
${ }^{73}$ Amos Yadlin, “Assad Must Go,” Ynet, May 18, 2016, http://www.ynetnews.com/ articles/0,7340,L-4804899,00.html.

${ }^{74}$ Author interview with Israeli official, Jerusalem, January 14, 2016.

${ }^{75}$ Author interview with Israeli official, Jerusalem, January 14, 2016.

${ }^{76}$ Author interview with former senior Israeli intelligence official, Tel Aviv, January $17,2016$.

${ }^{77}$ It is also interesting to note that, in the aftermath of the nuclear agreement, the Saudis have become more aggressive while Israel has become more reserved in its approach to Iran. This might be because what the Saudis fear is a U.S. pivot to Iran away from Saudi Arabia, while the Israelis are more confident in the U.S.Israeli relationship and do not fear a broader pivot. Thanks to Ilan Goldenberg for this observation.

78 "In Very Rare Public Meet, Israeli, Saudi Officials Name Iran as Common Foe," Times of Israel, June 5, 2015,

http://www.timesofisrael.com/

in-rare-meet-israeli-saudi-officials-name-iran-as-common-foel.

${ }^{79}$ Hagar Shezaf, "Israel Eyes Improved Ties with Gulf States After 'Foothold' Gained in UAE,” Middle East Eye, January 18, 2016,

http://www.middleeasteye.net/news/

israel-eyes-improved-gulf-states-relationship-ties-flourish-uae-895004700.

${ }^{80}$ Author interview with Israeli official, Jerusalem, January 14, 2016.

${ }^{81}$ Author interview with Israeli official, Jerusalem, January 14, 2016.

${ }^{82}$ See Jacob Poushter, “The Middle East's Sectarian Divide on Views of

Saudi Arabia, Iran,” Pew Research Center, January 7, 2016,

http://www.pewresearch.org/fact-tank/2016/01/07/

the-middle-easts-sectarian-divide-on-views-of-saudi-arabia-iran/.

${ }^{83}$ See Ronen Bergman, “Will Israel Attack Iran?” New York Times Magazine, January 25, 2012, http://www.nytimes.com/2012/01/29/magazine/

will-israel-attack-iran.html?_r=0. In reports several years later, former Israeli

Defense Minister Ehud Barak claimed that he and Netanyahu were prepared to attack Iran but faced resistance from military leaders and later from other cabinet ministers. See Jodi Rudoren, "Israel Came Close to Attacking Iran, Ex-Defense Minister Says," New York Times, August 22, 2015,

http://www.nytimes.com/2015/08/22/world/middleeast/

israel-came-close-to-attacking-iran-ex-defense-minister-says.html.
${ }^{84}$ Author interview with former Israeli defense official, Tel Aviv, January 17, 2016.

${ }^{85}$ Author interview with former Israeli defense official, Tel Aviv, January 17, 2016. This former official said that after April 2013 - when U.S. negotiations with Iranians in Oman became serious - the Americans told Israeli leaders that they should start preparing for an agreement.

${ }^{86}$ Efraim Inbar, "Six Strikes Against the Nuclear Deal with Iran,” BESA Center Perspectives Paper No. 301, Ramat Gan, Israel: Begin-Sadat Center for Strategic Studies, July 15, 2015, http://besacenter.org/perspectives-papers/ six-strikes-against-the-nuclear-deal-with-iran/.

${ }^{87}$ Amos Harel, "Why Netanyahu Deserves Credit for Iran Nuclear Deal," Haaretz, July 18, 2015, http://www.haaretz.com/israel-news/.premium-1.666413.

${ }^{88}$ Author interview with former military official, Tel Aviv, January 13, 2016.

${ }^{89}$ For an analysis of Israel's policies in cyberspace, see Matthew S. Cohen, Charles D. Freilich, and Gabi Siboni, "Israel and Cyberspace: Unique Threat and Response," International Studies Perspectives, 2015, pp. 1-15.

${ }^{90}$ Halevi made this comment in an off-the-record, closed-door lecture to donors and faculty of the Israeli College of Management Studies in Tel Aviv. See "Rosh Aman: Anu Be’milhama Technologit Im Iran Ve'hem Metsamtsemim Pearim” ["Head of DMI: We Are in a Technological War with Iran and They Are Narrowing Gaps”], Haaretz, November 1, 2015, http://www.haaretz.co.il/news/ politics/1.2765400. Shira Efron translated the quotes from Hebrew.

${ }^{91}$ Author interview with former military official, Tel Aviv, January 13, 2016.

${ }^{2}$ Steven Erlanger, "Netanyahu Asserts Israel Will Be Iran's Watchdog," New York Times, January 17, 2016, http://www.nytimes.com/2016/01/18/world/middleeast/ netanyahu-asserts-israel-will-be-irans-watchdog.html.

${ }^{93}$ Author interview with Israeli official, Jerusalem, January 14, 2016. This official asserted that Iran is providing Hamas's military wing with tens of millions of dollars now that Hamas is being squeezed by Egypt, as well as advanced weapons and training to Hizballah forces in Syria.

${ }^{94}$ Author interview with Israeli officials, Jerusalem, January 14, 2016.

${ }^{95}$ Author interview with Israeli analyst, Tel Aviv, January 17, 2016. 
${ }^{96}$ Author interview with Israeli analyst, Jerusalem, January 14, 2016. Another Israeli analyst similarly viewed the attention on Israel's submarine fleet as signaling strengthened second-strike capabilities, although he noted that the debate in Israel focused more on how the submarine hangar would ruin the views in Haifa more than on the purpose of the submarines themselves (author interview with Israeli analyst, Tel Aviv, January 17, 2016). Other Israeli experts questioned whether a fifth submarine was a necessary expenditure to maintain deterrence, raising reservations about defense expenditures post-deal. See, for example, "Sdakim Be'maim Amukim: Ha’paranoya Shel Rosh Ha’memshala Me'haiyum Ha'Irani" ["Cracks in Deep Water: The Prime Minister's Paranoia of the Iranian Threat"], Maariv, December 23, 2015,

http://www.maariv.co.il/journalists/Article-518841

${ }^{97}$ Author interview with former senior military official, Tel Aviv, January 13, 2016.

${ }^{98}$ See Kenneth Katzman, Iran: Politics, Gulf Security, and U.S. Policy, Washington, D.C.: Congressional Research Service, March 30, 2016, https://www.fas.org/sgp/ crs/mideast/RL32048.pdf.

${ }^{99}$ Julie Hirschfeld Davis, "Obama-Netanyahu Rift Impedes U.S. Offer of Record Aid Deal for Israel," New York Times, April 28, 2016

http://www.nytimes.com/2016/04/29/world/middleeast/30prexy.html.

${ }^{100}$ See, for example, Dan Williams, Patricia Zengerle and Matt Spetalnick, "Differences over Missile Defense, Fine Print Snag U.S.-Israel Aid Deal," Reuters, May 5, 2016, http://www.reuters.com/article/ us-usa-israel-defence-exclusive-idUSKCNOXU1UQ.
${ }^{101}$ Amir Rappaport analyzed the background for and objectives of the meeting between former Israeli Defense Minister Yaalon and his U.S. counterpart, Carter, with a focus on the memorandum of understanding; see "Pgisha Goralit Be'Washington" ["A Crucial Meeting in Washington"], Israel Defense Magazine, October 23, 2015

${ }^{102}$ For the outlines of a U.S. strategy following the nuclear agreement, including policy recommendations for U.S.-Israeli relations, see Ilan Goldenberg, Elizabeth Rosenberg, Avner Golov, Nicholas Heras, Ellie Maruyama, and Axel Hellman, The Iran Agreement and What Comes Next, Washington, D.C.: Center for New American Security, September 14, 2015, http://www.cnas.org/publications/ iran-agreement-and-what-comes-next\#.V6BlnmU4Tdk.

${ }^{103}$ Michael Herzog outlines some of the key differences between Israeli and U.S views on the JCPOA and broader threat assessments of Iran in "Iran Still Looms Large in Israel's Threat Perception," Policywatch 2659, Washington, D.C.: Washington Institute for Near East Policy, July 15, 2016,

http://www.washingtoninstitute.org/policy-analysis/view/ iran-still-looms-large-in-israels-threat-perception.

${ }^{104}$ Author interview with former Israeli security official, Tel Aviv, January 13, 2016.

${ }^{105}$ Author interview with former Israeli security official, Tel Aviv, January 13, 2016. 



\section{About This Perspective}

This research was supported through philanthropic contributions and conducted within the RAND Center for Middle East Public Policy (CMEPP), part of International Programs at the RAND Corporation. CMEPP brings together analytic excellence and regional expertise from across the RAND Corporation to address the most critical political, social, and economic challenges facing the Middle East today. For more information about the RAND Center for Middle East Public Policy, visit www.rand.org/cmepp or contact the director (contact information is provided on the web page).

I appreciate the excellent comments from Ilan Goldenberg and Larry Hanaver, who both carefully reviewed an earlier draft of this report. Their edits and suggestions significantly strengthened the final publication. Shira Efron also reviewed the full report and contributed valuable background material. Many thanks also to my colleagues Ali Nader and Robin Meili, who also read an early draft, as well as to Erin Smith for guiding this report through to publication. I am also grateful to Rebecca Fowler for editing assistance. And, most important, I am extremely grateful for the strategic guidance and philanthropic support from members on the Center for Middle East Public Policy advisory board, who made this report possible.

\section{About the Author}

Dalia Dassa Kaye is the director of the Center for Middle East Public Policy and a senior political scientist at the RAND Corporation.

\section{Limited Print and Electronic Distribution Rights}

This document and trademark(s) contained herein are protected by law. This representation of RAND intellectual property is provided for noncommercial use only. Unauthorized posting of this publication online is prohibited. Permission is given to duplicate this document for personal use only, as long as it is unaltered and complete. Permission is required from RAND to reproduce, or reuse in another form, any of our research documents for commercial use. For information on reprint and linking permissions, please visit www.rand.org/pubs/permissions.html.

The RAND Corporation is a research organization that develops solutions to public policy challenges to help make communities throughout the world safer and more secure, healthier and more prosperous. RAND is nonprofit, nonpartisan, and committed to the public interest.

RAND's publications do not necessarily reflect the opinions of its research clients and sponsors. RAND ${ }^{\circledR}$ is a registered trademark.

For more information on this publication, visit www.rand.org/t/PE207.

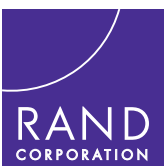

www.rand.org 